\title{
Chironomids in Quaternary permafrost deposits in the Siberian Arctic
}

\author{
Larisa Nazarova
}

Alfred Wegener Institute for Polar and Marine Research, Telegrafenberg A43, 14473 Potsdam, Germany; Kazan Federal University, Kremlyovskaya str., 18420008 Kazan, Russia

E-mail: nazarova larisa@mail.ru

Fossil chironomids from lacustrine sediments are frequently used as bioindicators for the reconstruction of Late Quaternary environments (Smol et al. 2005; Self et al. 2011), but there are very few records concerning chironomids from periglacial permafrost deposits (Ilyashuk et al. 2006).

Permafrost records, accessible at outcrops along the coast of Oyogos Yar at the NE-Siberian Dmitry Laptev Strait provided unique insights into the environmental history of Beringia during the last interglacial (Kienast et al. 2011). A paleontological study was carried out on the last interglacial (Kazantsevo, Eemian, Sangamoian, MIS 5) terrestrial and freshwater organism assemblages preserved in frozen deposits of a shallow paleo-lake outcropped at a permafrost cliff at Oyogos $\operatorname{Yar}\left(72.68^{\circ} \mathrm{N} ; 143.53^{\circ} \mathrm{E}\right)$, the mainland coast of the NE-Siberian Dmitry Laptev Strait, Republic Yakutia, in the Russian Federation (Fig. 1). The Dmitry Laptev

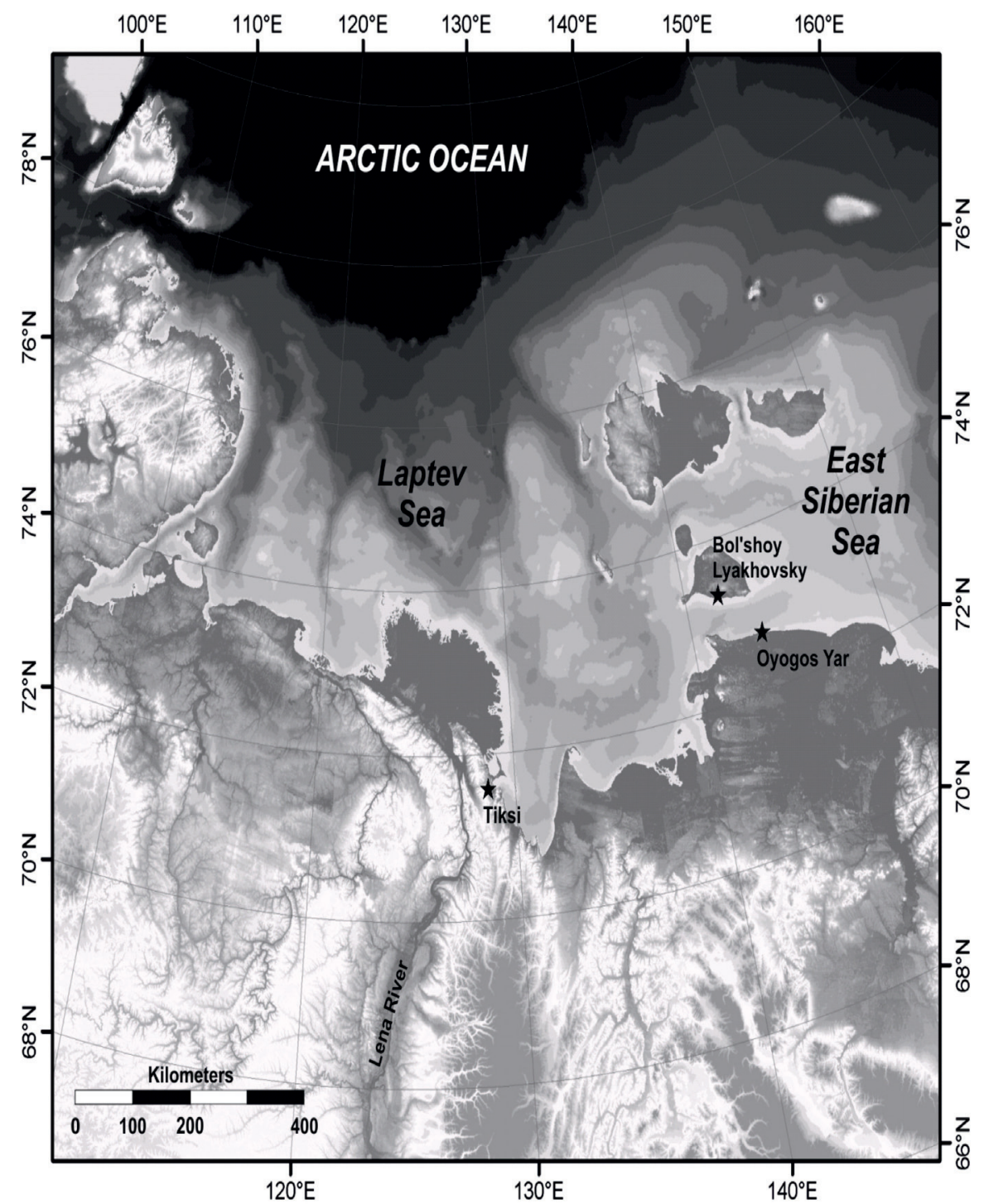

Figure 1. Location of the Bolshoj Ljakhobskiy Island and coastal sector of Oyogos Yar in north-eastern Siberia. 
Strait connects the Laptev and East Siberian seas, which are the widest and shallowest shelves worldwide. The mean temperature of the warmest month at the coast is about $4{ }^{\circ} \mathrm{C}$, the mean temperature of the coldest month is about $-30^{\circ} \mathrm{C}$ (Station Cape Svyatoy Nos, $7^{\circ}{ }^{\circ} 3^{\prime}$ N $, 140^{\circ}, 45^{\prime}$ E in Rivas-Martínez, 1996-2009).

From a total of 50 chironomid head capsules, recovered from Eemian deposits, 16 taxa were identified (Table 1). Eight of these taxa belong to the subfamily Orthocladiinae and eight to the subfamily Chironominae (five Chironomini, three Tanytarsini). The dominant taxa were Limnophyes, Smittia foliacea-type and the Psectrocladius sordidellus-type. The majority of the taxa are indicators of temperate shallow lakes or littoral conditions that are associated with macrophytes. Limnophyes and the subdominant taxa, Metriocnemus eurynotus-type and Parametriocnemus/ Paraphaenocladius are also frequently associated with macrophytes (Cranston et al., 1983; Brodin, 1986). Furthermore, these taxa are typically indicative of lake level fluctuations (Massaferro \& Brooks, 2002). Smittia foliacea-type could be indicative of erosional processes or unstable lake level conditions (Cranston et al., 1983). The subdominant taxa Chironomus anthracinustype and Cricotopus laricomalis-type are among the most frequently occurring taxa in present-day Yakutian lakes and can be found in a broad range of ecological conditions (Nazarova et al., 2005, 2008, 2011). Tanytarsus pallidicornis-type 1 is characteristic of relatively warm and productive lakes (Brodin, 1986). In contrast, Tanytarsus lugens-type and Parakiefferiella triquetra-type are cold stenotherms, occurring in oligotrophic cold subarctic lakes (Walker \& Mathewes, 1989; Brodin, 1986). Brillia and Endochironomus albipennis-type often are associated with submerged wood and dead leaves (Cranston et al., 1983). Some species of the group E. albipennis-type are leaf or stem miners (Pinder \& Reiss, 1983).

The chironomid record indicates the presence of submerged coarse plant debris in the paleo-lake, most probably the remains of trees and shrubs. Most of the identified chironomids indicate shallow water conditions and a pronounced macrophyte zone (Cranston et al., 1983; Brodin, 1986).

The Eemian was an interglacial period which began about 130,000 years ago and ended about 114,000 years ago. It was the second-to-latest interglacial period of the current Ice Age, the most recent being the Holocene which extends to the present day. The prevailing Eemian climate is believed to have been similar to that of the Holocene. Comparison of the Eemian fauna and modern chironomid assemblages from the 35 small permafrost lakes of Bolshoj Ljakhobskiy Island and Oyogos Yar mainland coastal area has shown certain fuanistic differences (Table 1) with a higher proportion of cold tolerant taxa in modern chironomid assemblages. Remains of terrestrial and freshwater organisms, including chironomids, preserved in frozen deposits of a shallow Eemian paleo-lake indicate a boreal climate at today's Arctic during that time. The use of transfer functions on the base of chironomid assemblages (Nazarova et al. 2011) brought a mean July air temperature reconstruction of $12.9 \pm 0.9^{\circ} \mathrm{C}$ and a water depth of $1.00 \pm 0.34 \mathrm{~m}$ for the time of deposition.

Table 1. Eemian chironomid fauna from Oygos Yar permafrost deposits and most frequent chironomid taxa from Bolshoj Ljakhobskiy Island and Oyogos Yar mainland coastal area (Northern Yakutia, Russia. Taxa that are found in modern and in Eemian sediments are given in bold.

\begin{tabular}{|c|c|c|c|}
\hline \multicolumn{2}{|c|}{ Modern lake deposits } & \multicolumn{2}{|c|}{$\begin{array}{l}\text { Eemian Permafrost deposirs } \\
(130,000 \text { to } 114,000 \text { years ago })\end{array}$} \\
\hline 16 most frequent taxa & $\%$ & Taxa & $\%$ \\
\hline Paratanytarsus penicillatus-type & 22.4 & Limnophyes* & 22.0 \\
\hline Chironomus anthracinus-type & 17.0 & Smittia foliacea-type & 18.0 \\
\hline Psectrocladius sordidellus-type & 13.9 & Psectrocladius sordidellus-type & 14.0 \\
\hline Orthocladius type I & 10.1 & Chironomus anthracinus-type & $6 . \beta$ \\
\hline Derotanypus & 5.4 & Cricotopus (I.) laricomalis & 6.0 \\
\hline Chironomini larvula & 2.9 & Metriocnemus eurynotus & 6.0 \\
\hline Limnophyes & 2.7 & Parametriocnemus & 6.0 \\
\hline Corynoneura arctica-type & 2.7 & Brillia & 4.0 \\
\hline Paratanytarsus austriacus-type & 2.2 & Microtendipes pedellus-type & 4.0 \\
\hline Cladotanytarsus mancus type 1 & 1.9 & Endochoronomus albipennis-type & 2.0 \\
\hline Orthocladius oliveri-type & 1.3 & Parachironomus varus-type & 2.0 \\
\hline Metriocnemus eurynotus-type & 1.2 & Parakiefferiella triquetra-type & 2.0 \\
\hline Orthocladius type S & 1.2 & Polypedilum nubeculosum-type & 2.0 \\
\hline Trissocladius & 1.2 & Zavrelia & 2.0 \\
\hline Acricotopus & 1.2 & Tanytarsus lugens-type & 2.0 \\
\hline Tanytarsus lugens-type & 1.1 & Tanytarsus pallidicornis-type 1 & 2.0 \\
\hline
\end{tabular}




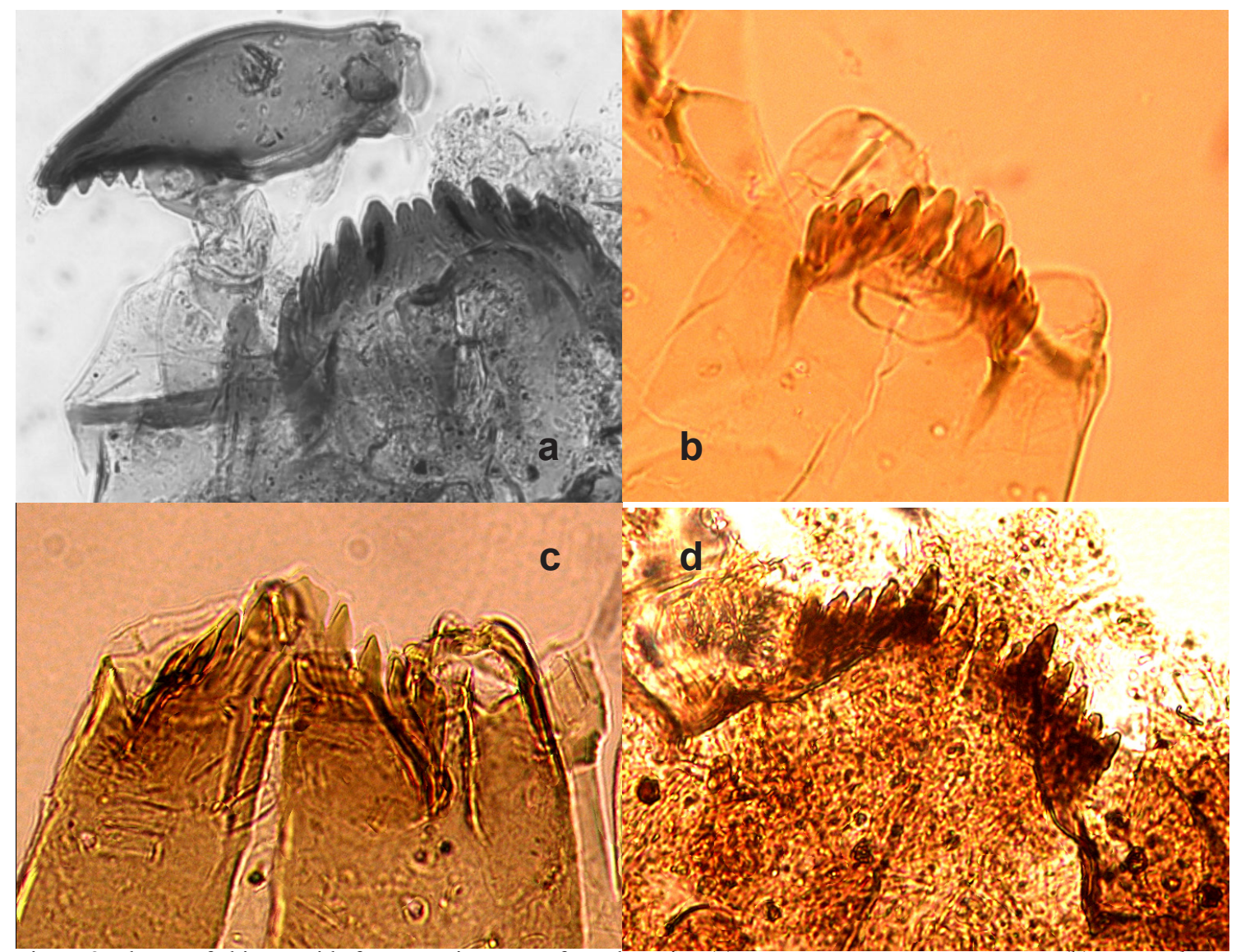

Figure 2. Photos of chironomids from Eemian permafrost deposits: (a) Metriocnemus eurynotus-type; (b) Limnophyes; (c) Smittia foliacea-type; (d) Microtendipes pedellus-type.

\section{References}

Brodin, Y. 1986. The postglacial history of Lake Flarken, interpreted from subfossil insect remains. - Internationale Revue der gesamten Hydrobiologie, 71: 371-432.

Cranston, P.S., Oliver, D.R. and Saether, O.A. 1983. The larvae of Othocladiinae (Diptera: Chironomidae) of the Holarctic region - keys and diagnoses. In: Wiederholm (ed.): Chironomidae of the Holarctic region, Part 9. - Entomologica Scandinavica Supplement 19: 149-291.

Ilyashuk, B.P., Andreev, A.A., Bobrov, A.A., Tumskoy, V.E. and Ilyashuk, E.A. 2006. Interglacial history of a palaeo-lake and regional environment: a multi-proxy study of a permafrost deposit from Bol'shoy Lyakhovsky Island, Arctic Siberia. - Journal of Paleolimnology. 35: 855-872

Kienast, F., Wetterich, S., Kuzmina, S., Schirrmeister, L., Andreev, A., Tarasov, P., Nazarova, L., Kossler, A., Frolova, L. and Kunitsky, V. 2011. Paleontological records prove boreal woodland under dry inland climate at today's Arctic coast in Beringia during the last interglacial. - Quaternary Science Reviews 31 2134-2159.

Massaferro, J. and Brooks, S., 2002. The response of chironomids to Late Quaternary climate change in the Taitao Peninsula, southern Chile. - Journal of Quaternary Science 17: 101-111.

Nazarova, L., Kumke, T., Pestryakova, L. and Hubberten, H.-W., 2005. Chironomid fauna of Central Yakutian lakes (Northern Russia) in palaeoenvironmental investigations. - Chironomus Newsletter on Chironomidae Research 18: 25-27.

Nazarova, L.B., Pestryakova, L.A., Ushnitskaya, L.A. and Hubberten, H.-W. 2008. Chironomids (Diptera: Chironomidae) in lakes of Central Yakutia and their indicative potential for paleoclimatic research. Sibirskii Ekologicheskii Zhurnal, 15 (3): 141-150 (in Russian). 
Nazarova, L., Herzschuh, U., Wetterich, S., Kumke, Th. and Pestjakova, L. 2011. Chironomid-based inference models for estimating mean July air temperature and water depth from lakes in Yakutia, northeastern Russia. - Journal of Paleolimnology. DOI: 10.1007/s10933-010-9479-4.

Pinder, L.C.V. and Reiss, F., 1983. The larvae of Chironominae (Diptera: Chironomidae) of the Holarctic region. - Keys and diagnoses. In: Wiederholm (ed.): Chironomidae of the Holarctic region, Partb10. Entomologica Scandinavica Supplement 19: 293-435.

Rivas-Martínez, S. 1996-2009. Climate diagrams, Worldwide Bioclimatic Classification System. Internet source, http://www.globalbioclimatics.org/plot/diagram.htm, Phytosociological Research Center, Spain.

Self, A.E., Brooks, S.J., Birks, H.J.B., Nazarova, L., Porinchu, D., Odland, A., Yang, H. and Jones, V.J. 2011. The distribution and abundance of chironomids in high-latitude Eurasian lakes with respect to temperature and continentality: development and application of new chironomid-based climate-inference models in northern Russia. - Quaternary Science Reviews. 30 1122-1141

Smol, J.P., Wolfe, A.P., Birks, H.J.B., Douglas, M.S.V., Jones, V.J., Korhola, A., Pienitz, R., Rühland, K, Sorvari, S, Antoniades, D., S.J. Brooks, S.J., Fallu, M.-A., Hughes, M, Keatley, B., Laing, T., Michelutti, N., Nazarova, L., Nyman, M., Paterson, A.M, Perren, B., Quinlan, R., Rautio, M., Saulnier-Talbot, É., Siitonen, S., Solovieva, N. and Weckström, J. 2005. Climate-Driven Regime Shifts in the biological communities of Arctic lakes. - Proceedings of the National Academy of Sciences of the United States of America 102: 4397-4402.

Walker, I.R. and Mathewes, R.W. 1989. Early postglacial chironomid succession in southwestern British Columbia, Canada, and its paleoenvironmental significance. - Journal of paleolimnology 2: 1-14. 